\title{
Evaluation of Adhesive Remnant Index after metal brackets removal using AutoCAD software
}

\author{
Adriana Arbutina', Marijana Arapović-Savić', Mirjana Umićević-Davidović', Irena Kuzmanović \\ Radman'2, Saša Marin ${ }^{3}$ \\ ${ }^{1}$ University of Banja Luka, Faculty of Medicine, Department of Orthodontics, Banja Luka, Republika Srpska, Bosnia and \\ Herzegovina; \\ ${ }^{2}$ University of Banja Luka, Faculty of Medicine, Department of Restorative Dentistry and Endodontics, Banja Luka, Republika \\ Srpska, Bosnia and Herzegovina; \\ ${ }^{3}$ University of Banja Luka, Faculty of Medicine, Department of Oral Surgery, Banja Luka, Republika Srpska, Bosnia and \\ Herzegovina
}

\begin{abstract}
SUMMARY
Introduction After the completion of treatment with fixed orthodontic appliances, it is necessary to remove the brackets and bands from teeth using an appropriate method. The aim of this study was to determine the most common way of bond failure between teeth and metal brackets, as well as to compare bond failure between the brackets and upper and lower premolars.

Material and Method Metal brackets were bonded with Aspire composite material on 154 human premolars, extracted for orthodontic purposes. After debonding, the surface of remaining adhesive on the teeth and brackets was measured. Adhesive Remnant Index (ARI) was used to estimate bond failure between teeth and metal brackets.

Results The average size of remaining adhesive surface after removing brackets from the upper premolars was 12.06 $\mathrm{mm}^{2}$, while it was $9.32 \mathrm{~mm}^{2}$ on the lower premolars. The average size of the remaining adhesive surface area on the brackets removed from the upper premolars was $0.37 \mathrm{~mm}^{2}$, while it was $2.08 \mathrm{~mm}^{2}$ on the brackets removed from lower premolars. A statistically significant difference was found between these values. The most common score of $A R I_{\text {tee }}$ was $3(85.71 \%)$ and the most frequent score of $A R I_{\text {brackets }}$ was 0 (85.71\%).

Conclusion The most common way of bond failure between teeth and metal brackets was between the bracket base and adhesive surface. A statistically significant difference was found between the values of the size of residual adhesive surface on the upper and lower premolars as well as on the brackets debonded from them.
\end{abstract}

Keywords: bracket removal; surface of residual adhesive; Adhesive Remnant Index (ARI)

\section{INTRODUCTION}

Treatment with fixed orthodontic appliances is one of the most frequently used procedures for correcting orthodontic irregularities and achieving proper occlusal relationships. After completion of orthodontic treatment, it is necessary to remove brackets and bands from the teeth as well as the remaining adhesive. Debonding of the brackets depends on the type of brackets used (metal, ceramic or plastic). Metal brackets are usually removed using the appropriate orthodontic pliers and force of traction, torsion or shearing $[1,2]$.

Several factors may influence enamel-bracket shear bond strength: the type of adhesive systems used for bonding brackets, the type and duration of enamel etching, the size and type of brackets, the design of bracket base and oral environmental factors. These factors and the type of debonding procedure affect the type of bond failure between teeth and brackets as well as the amount of remaining adhesive on both [3-6].

Optimal bond strength between teeth and metal brackets ranges from $5.9 \mathrm{MPa}$ to $8 \mathrm{MPa}$. If bond strength is greater than these values, it is possible to cause enamel damage during debonding procedure. The highest risk of enamel fracture is present at the moment of bracket debonding. Plaque accumulation and tooth pigmentation often occurs in the area of these fractures. During bracket debonding, bond failure can occur: on the bracket, between the bracket and adhesive, on adhesive, between enamel and adhesive, on enamel or mixed type of bond failure may occur. It is desirable that, after removing brackets, adhesive completely remains on the surface of a tooth to avoid possibility of enamel microcracks and fractures $[2,7,8,9]$.

As per literature, bond failure between adhesive and a bracket base is the most common [10-14]. Some authors correlated morphological characteristics of teeth and mode of bond failure between teeth and brackets, due to larger amounts of adhesive found to remain on buccal surfaces of upper teeth in comparison to lower teeth, after bracket removal. Studies by Hobson at al. and Ozturk at al. concluded that differences in morphological characteristics among groups of teeth affect shear bond strength between brackets and teeth, regardless of the type of adhesive system used 
$[15,16]$.Zannarini at al. also noted difference between the values of remaining adhesive surface on bracket bases on the upper and lower teeth, namely between upper and lower incisors and upper and lower canines. They found higher amount of adhesive remained on the brackets removed from the upper teeth in relation to the lower teeth [17].

One of the most commonly used methods for determining the mode of bond failure between a tooth surface and a bracket base is the use of Adhesive Remnant Index (ARI), which was introduced by Artun and Bergland in 1984 [18]. According to this index, it is possible to precisely determine location of bond failure using different types of brackets and adhesive systems. To analyze the surface of residual adhesive on teeth and brackets, stereomicroscopy is often used, as well as the appropriate computer software $[17,19,20]$.

The aim of this study was to determine the most frequent mode of bond failure between teeth and metal brackets using the ARI index and AutoCAD program, and to compare bond failure between upper and lower premolars and metal brackets.

\section{MATERIAL AND METHOD}

For the study, 154 human premolars extracted for orthodontic purposes were collected (77 upper premolars and 77 lower premolars). The tooth selection criteria implied that teeth had an intact oral and buccal surface without visible damage, white spots and carious lesions, and they had not been previously exposed to chemicals such as hydrogen peroxide or an acid for the purpose of etching. The teeth were kept until the beginning of the study in saline with $0.1 \%$ thymol to prevent dehydration. Prior to the experiment, the teeth were mechanically cleaned with a brush and non-abrasive non-fluoride paste. The middle third of the buccal surface of each tooth was treated with $38 \%$ orthophosphoric acid for 20 seconds and then rinsed with water for 30 seconds and dried for another $30 \mathrm{sec}-$ onds. Buccal surface of 154 teeth was primed with Aspire orthodontic adhesive 7GM (OC Orthodontics, USA), according to the manufacturer's instructions and then polymerized for 10 seconds. Metal brackets (Ortho Organizer Elite OptiMIM, Henry Schein Orthodontics, USA) were bonded to the prepared surface of tooth with Aspire orthodontic adhesive 5GM (OC Orthodontics, USA) and light cured for 40 seconds according to the manufacturer's instructions (Figure 1 and 2).

The teeth were left in artificial saliva at the room temperature for 48 hours to allow the adhesive system to reach its maximum strength. Biotene gel (GlaxoSmithKline, Belgium) was used as a source of artificial saliva. The brackets were debonded with Ixion bracket removing pliers (DB Orthodontics, West Yorkshire, UK). After a sample preparation process, digital photographs of the buccal surfaces and the bracket bases were taken with a digital camera Nikon D5100. The procedure was carried out using a macroscopic lens at an appropriate distance of $20 \mathrm{~cm}$. The sample was placed on a millimeter scale foil that served as a reference measure for the calibration for
AutoCAD software (Autodesk inc. San Rafael, CA, USA) [21]. AutoCAD software is the most commonly used $\mathrm{Au}-$ todesk program for designing engineering project documentation in 2D and 3D design. In this study, it was used to determine the surface of the remaining adhesive on a tooth and bracket as well as to determine the surface of a bracket base. Since the measurement was performed in millimeters, the images were calibrated so that the lengths in the program are set in millimeters. After calibrating the images in AutoCAD, the polyline lines in the form of "closed polygons" overlaid the surface of the remaining adhesive on the tooth and the base of the bracket, as well as the bracket base surface, and the values of marked parameters were automatically obtained (Figure 3 ).

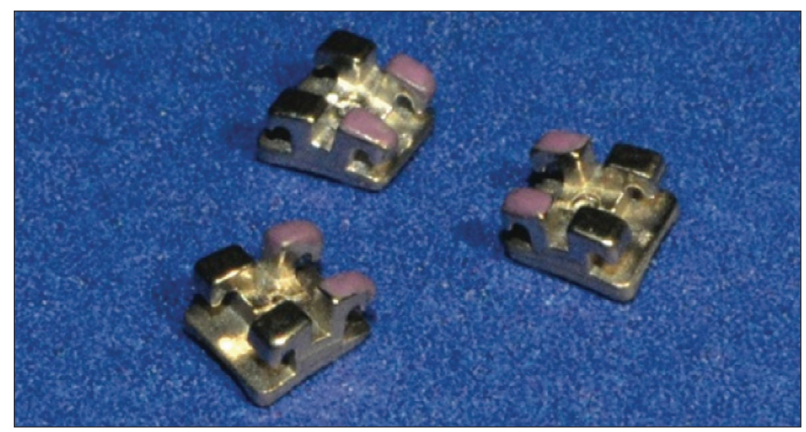

Figure 1. Brackets Ortho Organizers Elite OptiMIM Slika 1. Bravice Ortho Organizers Elite OptiMIM

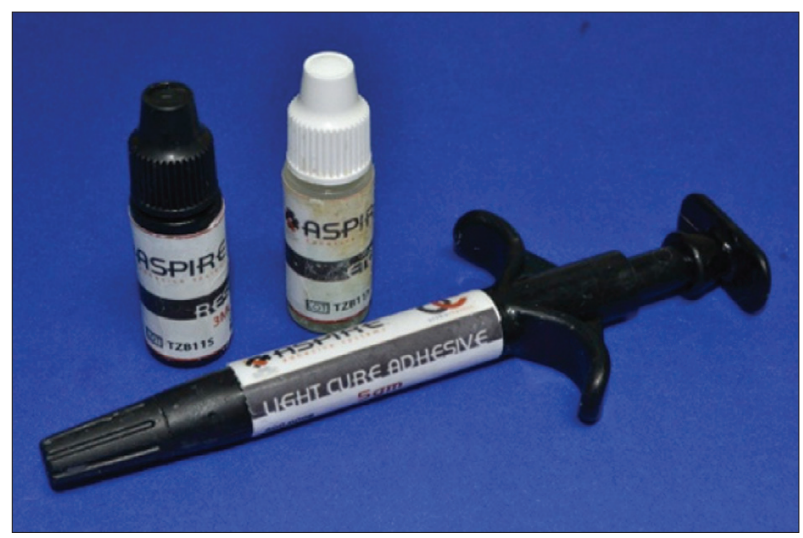

Figure 2. Aspire orthodontic adhesive system Slika 2. Ortodontski adhezivni sistem Aspire

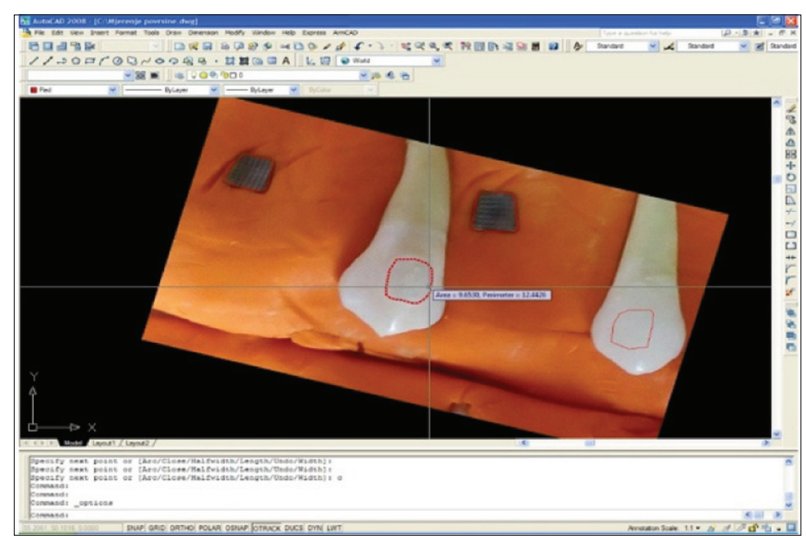

Figure 3. Analysis of the remaining adhesive on the teeth and brackets and measurement of the brackets surface size using AutoCAD software

Slika 3. Određivanje površine preostalog adheziva na zubu i na bravici, kao i površine baze bravice korišćenjem programa AutoCAD 
The value of the remaining adhesive surface on teeth was evaluated according to the ARI ${ }_{\text {teeth }}$ scores from 0 to 3 as follows: face,

score 0 - $0 \%$ of the remaining adhesive on enamel sur-

score 1 - less than $50 \%$ of the remaining adhesive on the surface of a tooth,

score 2 - more than $50 \%$ of the remaining adhesive on the tooth surface and

score $3-100 \%$ of the remaining adhesive on the tooth surface.

The residual adhesive surface on bracket bases was evaluated by the $\mathrm{ARI}_{\text {brackets }}$ as follows:

score 0 - less than $10 \%$ of remaining adhesive on the surface of the bracket,

score 1 - more than $10 \%$ but less than $50 \%$ of remaining adhesive on the surface of the bracket,

score 2 - more than $50 \%$ but less than $90 \%$ of adhesive remaining on the surface of the bracket and

score 3 - more than $90 \%$ of adhesive on the surface of the bracket [18].

Qualitative data (ARI scores) were presented by the number of occurrences and percentages. Descriptive statistic indicators (arithmetic mean, standard deviation, extreme values) were used to show the surface of the remaining adhesive on teeth and brackets after debonding. Parametric Student t-test for independent samples was used to compare the mean values of the characteristics. A statistically significant difference was defined as $p<0.05$, with values in which $p<0.01$ were stated as statistically very significant. Pearson's parametric correlation was used to determine the degree of correlation of the observed characteristics.

\section{RESULTS}

The average value of metal bracket base surfaces Ortho Organizer Elite OptiMIM for premolars, which were bonded to 154 premolars, was $11.07 \mathrm{~mm}^{2}$. After removing the brackets, the AutoCAD program determined the surface of the remaining adhesive on the teeth and brackets. The average value of the remaining adhesive after removing the brackets from the upper premolars was 12.06 $\mathrm{mm}^{2}$, while this value at the lower premolars was 9.32 $\mathrm{mm}^{2}$. Student $\mathrm{t}$-test showed that there was a statistically significant difference between the values of the remaining adhesive surfaces on the upper and lower premolars after removing the brackets (Table 1).

The average value of the remaining adhesive surface on the brackets removed from the upper premolars was $0.37 \mathrm{~mm}^{2}$, while this value at the lower premolars was $2.08 \mathrm{~mm}^{2}$. Student t-test showed a statistically significant difference between the values of the remaining adhesives on the brackets removed from the upper and lower premolars (Table 2).

Tables 3 and 4 show the distribution of ARI $I_{\text {teeth }}$ and $\mathrm{ARI}_{\text {brackets }}$ for the upper and lower premolars. The most

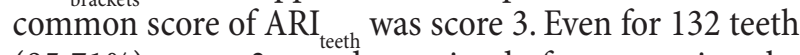
$(85.71 \%)$, score 3 was determined after removing the
Table 1. The surface of remaining adhesive on the upper and lower premolars

Tabela 1. Površina preostalog adheziva na gornjim i donjim premolarima

\begin{tabular}{|l|c|c|c|c|c|c|c|}
\hline $\begin{array}{l}\text { Surface of residual } \\
\text { adhesive }\left(\mathbf{m m}^{2}\right) \\
\text { Površina preostalog } \\
\text { adheziva }\left(\mathbf{m m}^{2}\right)\end{array}$ & $\mathbf{n}$ & $\mathbf{M} \pm \mathbf{S D}$ & $\mathbf{M i n}$ & $\mathbf{M a x}$ & $\mathbf{t}$ & $\mathbf{d f}$ & $\mathbf{p}$ \\
\hline $\begin{array}{l}\text { Upper premolars } \\
\text { Gornji pretkutnjaci }\end{array}$ & 77 & $12.06 \pm 2.14$ & 0 & 15.48 & & & \\
\hline $\begin{array}{l}\text { Lower premolars } \\
\text { Donji pretkutnjaci }\end{array}$ & 77 & $9.32 \pm 4.45$ & 0 & 14.91 & 4.86 & 109.5 & $<\mathbf{0 . 0 1}$ \\
\hline $\begin{array}{l}\text { Total } \\
\text { Ukupno }\end{array}$ & 154 & $10.69 \pm 3.74$ & 0 & 15.48 & & & \\
\hline
\end{tabular}

Table 2. The surface of remaining adhesive on brackets removed from the upper and lower premolars

Tabela 2. Osnovni pokazatelji deskriptivne statistike za površinu preostaloga adheziva na bravicama koje su uklonjene sa gornjih i donjih premolara

\begin{tabular}{|c|c|c|c|c|c|c|c|}
\hline $\begin{array}{l}\text { Surface of residual } \\
\text { adhesive on the } \\
\text { bracket }\left(\mathrm{mm}^{2}\right) \\
\text { Površina preostalog } \\
\text { adheziva na bravici } \\
\left(\mathrm{mm}^{2}\right)\end{array}$ & n & $M \pm S D$ & Min & Max & $t$ & df & p \\
\hline $\begin{array}{l}\text { Upper premolars } \\
\text { Gornji pretkutnjaci }\end{array}$ & 77 & $0.37 \pm 1.74$ & 0 & \begin{tabular}{|l|l} 
& 12.2 .2
\end{tabular} & & & \\
\hline $\begin{array}{l}\text { Lower premolars } \\
\text { Donji pretkutnjaci }\end{array}$ & 77 & $2.08 \pm 4.27$ & 0 & 13.3 & 3.26 & 100.5 & $<0.01$ \\
\hline $\begin{array}{l}\text { Total } \\
\text { Ukupno }\end{array}$ & 154 & $1.23 \pm 3.36$ & 0 & 13.3 & & & \\
\hline
\end{tabular}

Table 3. Distribution of ARI teeth $_{\text {scos for }}$ for upper and lower premolars Tabela 3. Raspodela ocena ARI ${ }_{\text {zuba }}$ kod gornjih i donjih pretkutnjaka

\begin{tabular}{|c|c|c|c|c|c|}
\hline \multirow{2}{*}{$\begin{array}{l}\text { Premolars } \\
\text { Pretkutnjaci }\end{array}$} & \multicolumn{4}{|c|}{$\begin{array}{l}\text { ARI } \\
\text { ARI }_{\text {zubath }} \text { score } \\
\text { ocena }\end{array}$} & \multirow{2}{*}{$\begin{array}{l}\text { Total } \\
\text { Ukupno }\end{array}$} \\
\hline & 0 & 1 & 2 & 3 & \\
\hline $\begin{array}{l}\text { Upper } \\
\text { Gornji }\end{array}$ & $\begin{array}{c}1 \\
(1.3 \%) \\
\end{array}$ & $\begin{array}{c}1 \\
(1.3 \%)\end{array}$ & $\begin{array}{c}3 \\
(3.89 \%)\end{array}$ & $\begin{array}{c}72 \\
(93.51 \%) \\
\end{array}$ & $\begin{array}{c}77 \\
(100 \%)\end{array}$ \\
\hline $\begin{array}{l}\text { Lower } \\
\text { Donji }\end{array}$ & $\begin{array}{c}12 \\
(15.58 \%)\end{array}$ & $\begin{array}{c}1 \\
(1.3 \%)\end{array}$ & $\begin{array}{c}4 \\
(5.2 \%)\end{array}$ & $\begin{array}{c}60 \\
(77.92 \%)\end{array}$ & $\begin{array}{c}77 \\
(100 \%)\end{array}$ \\
\hline $\begin{array}{l}\text { Total } \\
\text { Ukupno }\end{array}$ & $\begin{array}{c}13 \\
(8.44 \%)\end{array}$ & $\begin{array}{c}2 \\
(1.3 \%)\end{array}$ & $\begin{array}{c}7 \\
(4.54 \%)\end{array}$ & $\begin{array}{c}132 \\
(85.71 \%)\end{array}$ & $\begin{array}{c}154 \\
(100 \%)\end{array}$ \\
\hline
\end{tabular}

Table 4. Distribution of ARI

Tabela 4. Raspodela ocena ARI

\begin{tabular}{|l|c|c|c|c|c|}
\hline \multirow{2}{*}{$\begin{array}{l}\text { Brackets } \\
\text { Bravice }\end{array}$} & \multicolumn{4}{|c|}{$\begin{array}{c}\text { ARI }_{\text {brackets }} \\
\text { ARI }_{\text {bravica }}\end{array}$} & $\begin{array}{c}\text { Total } \\
\text { Ukupno }\end{array}$ \\
\cline { 2 - 5 } & $\mathbf{0}$ & $\mathbf{1}$ & $\mathbf{2}$ & $\mathbf{3}$ & \\
\hline $\begin{array}{l}\text { For upper } \\
\text { premolars } \\
\text { Za gornje } \\
\text { pretkutnjake }\end{array}$ & $\begin{array}{c}72 \\
(93.51 \%)\end{array}$ & $\begin{array}{c}3 \\
(3.89 \%)\end{array}$ & $\begin{array}{c}1 \\
(1.3 \%)\end{array}$ & $\begin{array}{c}1 \\
(1.3 \%)\end{array}$ & $\begin{array}{c}77 \\
(100 \%)\end{array}$ \\
\hline $\begin{array}{l}\text { For lower } \\
\text { premolars } \\
\text { Za donje } \\
\text { pretkutnjake }\end{array}$ & $\begin{array}{c}60 \\
(77.92 \%)\end{array}$ & $\begin{array}{c}4 \\
(5.2 \%)\end{array}$ & $\begin{array}{c}1 \\
(1.3 \%)\end{array}$ & $\begin{array}{c}12 \\
(15.58 \%)\end{array}$ & $\begin{array}{c}77 \\
(100 \%)\end{array}$ \\
\hline $\begin{array}{l}\text { Total } \\
\text { Ukupno }\end{array}$ & $\begin{array}{c}132 \\
(85.71 \%)\end{array}$ & $\begin{array}{c}7 \\
(4.54 \%)\end{array}$ & $\begin{array}{c}2 \\
(1.3 \%)\end{array}$ & $\begin{array}{c}13 \\
(8.44 \%)\end{array}$ & $\begin{array}{c}154 \\
(100 \%)\end{array}$ \\
\hline
\end{tabular}

brackets, for 13 teeth $(8.44 \%)$ score was 0,7 teeth had score $2(1.3 \%)$, while only 2 teeth $(1.3 \%)$ had score 1 . The most common score of ARI brackets $_{\text {was }}$ score $0(132,85.71 \%) .13$ brackets $(8.44 \%)$ had score 3,7 brackets $(4.54 \%)$ had score 1 , while only 2 brackets (1.3\%) had score 2 . 
Table 5. Pearson correlation

Tabela 5. Pirsonova korelacija

\begin{tabular}{|c|c|c|c|c|c|}
\hline \multicolumn{2}{|l|}{$\begin{array}{l}\text { Pearson correlation } \\
\text { Pirsonova korelacija }\end{array}$} & \multirow{2}{*}{$\begin{array}{c}\text { ARI }{ }_{\text {brackets }} \text { for upper premolars } \\
\text { ARI }_{\text {bravica }}^{\text {za gornje pretkutnjake }} \\
.523^{* *}\end{array}$} & \multicolumn{2}{|l|}{$\begin{array}{l}\text { Pearson correlation } \\
\text { Pirsonova korelacija }\end{array}$} & $\begin{array}{l}A R I_{\text {teeth }} \text { for upper premolars } \\
A R I_{\text {zuba }} \text { za gornje pretkutnjake }\end{array}$ \\
\hline \multirow{2}{*}{$\begin{array}{l}A R I_{\text {brackets }} \text { for lower premolars } \\
A R I_{\text {bravica }} \text { za donje pretkutnjake }\end{array}$} & $r$ & & \multirow{2}{*}{$\begin{array}{l}A R I_{\text {teeth }} \text { for lower premolars } \\
\mathrm{ARI}_{\text {zuba }} \text { za donje pretkutnjake }\end{array}$} & $r$ & $.523^{* *}$ \\
\hline & $p$ & .001 & & $\mathrm{p}$ & .001 \\
\hline
\end{tabular}

** correlation significant at 0.01

** korelacija je značajna na nivou 0,01

Correlation between the average values of ARI teeth $_{\text {for }}$ the upper and lower premolars was determined by the Pearson coefficient of linear correlation. The statistically significant, positive and very strong correlation between the average values of ARI $\mathrm{I}_{\text {teet }}$ for the upper and lower premolar $(\mathrm{r}=.53, \mathrm{p}<.01)$ was found. Also, a statistically significant, positive and very strong correlation was found between the average values of ARI $\mathrm{brackts}_{\text {for brackets }}$ bonded to the upper and lower premolar $(\mathrm{r}=.53, \mathrm{p}<.01)$ (Table 5).

\section{DISCUSSION}

Since fixed appliances with metal brackets often represent a method of choice for achieving successful orthodontic treatment, metal brackets have been used in our research. After removing brackets from examined teeth, the difference between the amount of remaining adhesive surface on the brackets on the upper and lower premolars was determined, as well as the difference between the values of ARI brackets. .

Some authors reported difference between the size of remaining adhesive on the upper and lower teeth. Therefore, Zanarini at al. conducted their research on 100 metal brackets that were removed after completed treatment with fixed orthodontic appliances in 60 patients. Using the Image J program on photomicrographs obtained by scanning electron microscopy, they measured the size of remaining adhesive on brackets. They noted statistically significant difference in the size of remaining adhesive on the base of brackets between the teeth from upper and lower dental arch, which is in agreement with results of the current study [17].

The most commonly reported ARI teeth $_{\text {score in this }}$ study was 3 , followed by 0,2 and 1 . This result indicates that the most common mode of bond failure was between the adhesive and the base of the metal bracket that decreased the possibility of enamel microcracks. In vitro studies of Ryf at al., as well as Sing and Kumari, evaluated the mode of bond failure between the teeth and brackets, according to the ARI index. They also reported greater amount of remaining adhesive on teeth after metal brackets removal. The most frequent ARI score was 3 and it indicated that bond failure was most commonly found between the base of the bracket and resin [22,23].

ARI index can also be used in clinical studies where precise impressions of the teeth from which brackets have been removed are required. These studies may point significant influence of certain factors on the mode of bond failure between teeth and brackets that cannot fully be mimicked in in vitro studies. Some of them are: longer exposure time of brackets and adhesive to saliva and $\mathrm{pH}$ changes caused by certain type of drink and food, exposure of a fixed appliance to mastication force etc. Using teeth impressions study models can be obtained and observed with stereomicroscope. Photomicrographs can be taken as well. Scanning electron microscopy (SEM) can also be used for impressions analysis, and it can even more accurately determine the size of remaining adhesive on teeth. Some clinical studies did not show any difference in the ARI index values from the same parameters determined by experimental studies [24].

Bonetti at al. conducted their research on 12 dental students with metal brackets Victory Series; 3 Munitek, Monrovia; California, which were bonded using Transbond XT composite material, and metal brackets APC II Victory Series; 3M Unitek, with already fabricated adhesive. After removing brackets, they evaluated the surface of remaining adhesive on teeth and brackets using ARI index. They found no statistically significant difference in the distribution of ARI score between the two premolar groups, and the most common score was 3 , which is in accordance with the results of our study [25].

One of the factors affecting the mode of bond failure between teeth and brackets is also the type of brackets used. Thus, Mirzakouchaki at al. in their study on 120 intact human premolars with metal and ceramic brackets concluded that more adhesive remained on teeth that had ceramic brackets compared to metal one [7].

However, beside the bracket material, the retention mode (chemical or mechanical) and bracket base design can affect shear bond strength and the mode of bond failure during bracket removal. Henkin at al. investigated mode of bond failure for 7 different types of metal brackets (MorelliTM, American OrthodonticsTM, TP OrthodonticsTM, OrthometricTM, TecnidentTM, UnidentTM, Abzil-3MTM) attached to 105 bovine teeth. After their removal, the ARI index was determined by stereomicroscopy. They noted different distribution of ARI scores for teeth with different types of brackets attached. The most common score for the teeth with the UnidentTM brackets was 3, which is in accordance with the results of our research. On the teeth with other types of metal brackets attached, the most common score was 1 , which can be explained by different shape and structure of the metal bracket base. UnidentTM brackets have similar shape and mesh base structure as the OrthoOrganizer brackets used in our research, which could be the reason for obtaining similar results of the ARI index [10].

For the purpose of the current study, light-curing composite material Aspire (Ortho Classic Orthodontics, USA) 
was used, characterized by extended working hours. This resin is not transparent; therefore it is easier to notice it on the tooth surface. Some studies also emphasized the importance of the type of adhesive system used [26].

There has been noticed premature polymerization of the composite material used for bonding brackets under the influence of dental chair reflector in the process of bonding fixed orthodontic appliances. This applies to situations when material is bonded before bracket is placed in the correct position on a tooth surface. Tiwari et al. examined the influence of light of dental chair reflector on shear bond strength, as well as mode of bond failure between teeth and brackets when Transbond XT (3M Unitec, Monrovia, Callif, USA) light-cured composite material was used. Their study was performed on 60 human premolars, extracted for orthodontic purposes. The most common ARI score after bracket debonding was 3, indicating that the most frequent mode of bond failure was between a bracket base and adhesive. The authors concluded that dental chair reflector light did not have any significant effect on the shear bond strength and mode of bond failure between teeth and brackets [14].

In our study, difference in size of remaining residual adhesive after bracket debonding was found both on the brackets and examined teeth. However, our in vitro study included only premolars, while further studies could investigate the same parameters on incisors and molars due to different morphological characteristics of these teeth.

\section{CONCLUSION}

After removing metal brackets, the most frequent mode of bond failure was between adhesive and the base of bracket. A significant difference was found in the size of remaining adhesive both on the teeth and brackets between upper and lower premolars.

\section{REFERENCES}

1. Chen-Sheng C, Ming-Lun H, Kin-Di C, Shou-Hsin K, Ping-Ting C, Yih-Wen G. Failure analysis: Enamel fracture after debonding orthodontic brackets. Angle Orthod. 2008; 78:1071-7. [DOI: 10.2319/091907-449.1] [PMID: 18947273]

2. Ireland AJ, McDonald F. The Ortodontic Patient:Teratment and Biomechanics.Datastatus. Beograd; 2010.

3. Cakmak F, Kocak S, Kocak MM, Turk ES, Turk T. Comparison of shear bond strength of ceramic brackets using either self-etching primer or conventional primer after intracoronal bleahing. Turk J Orthod. 2015; 28:48-54.

[DOI: 10.5152/TurkJOrthod.2016.15-00006R2]

4. Flores T, Mayoral JR, Giner L, Puigdollers A. Comparison of enamel-bracket bond strength using direct- and indirect-bonding techniques with a self-etching ion releasing S-PRG filler. Dent Mat J. 2015; 34:41-7. [DOI: 10.4012/dmj.2014-138] [PMID: 25748457]

5. Zanini MM, Nassar CA, Nassar PO, Busato PMR, Favarao J, Busato MCA. Periodontal conditions in orthodontic patients using direct and indirect bonding techniques: A randomized study. J Dent Oral Hyg. 2016; 8:59-65. [DOI: 10.5897/JDOH2015.0176]

6. Atashi MHA, Khosravi S, Pakdel SMV. Clinical survival of rebonded brackets with different ARI scores. Adv Biosci Clin Med. 2016; 4:22-6. [DOI: 10.7575/aiac.abcmed.16.04.01.05]
7. Mirzakouchaki B, Shirazi S, Sharghi R, Shirazi S, Moghimi M, Shahrbaf S. Shear bond strength and debonding characteristics of metal and ceramic brackets bonded with conventional acidetch and self-etch primer systems: An in-vivo study. J Clin Exp Dent. 2016; 8:38-43. [DOI: 10.4317/jced.52658] [PMID: 26855704]

8. Guiraldo RD, Berger SB, Rocha FD, Pereira GMR, Aleixo AR, Correr $A B$. Evaluation of shear strength of brackets with different dental composites and enamel roughness. App Adh Sci. 2016; 4:1-8. [DOI: 10.1186/s40563-016-0065-5]

9. Hellak A, Rusdea P, Schauseil M, Stein S, Steiner HKM. Enamel shear bond strength of two orthodontic self-etching bonding systems compared to Transbond ${ }^{\mathrm{TM}}$ XT. J Orofacial Orthoped. 2016; 77:3919. [DOI: 10.1007/s00056-016-0046-0] [PMID: 27582286]

10. Henkin FS, Macedo EOD, Santos KS, Schwarzbach M, Samuel SMW, Mundstock KS. In vitro analysis of shear bond strength and adhesive remnant index of different metal brackets. Dent Press J Orthod. 2016; 21:67-73. [DOI: 10.1590/2177-6709.21.6.067-073.oar]

11. Scribante A, Contreras-Bulnes R, Montasser M, Vallitu PK. Orthodontics, bracket materials, adhesive systems and their bond strength. Bio Med Res Int. 2016; 2016:1-3.

[DOI: $10.1155 / 2016 / 1329814]$

12. Singh SK, Kumari S. Evaluation of adhesive remnant index (ARI) using Transbond XT and Self Etching Primer.J Res Adv Dent. 2014; 3:2007. [DOI: 10.1043/0003-3219(2006)076[0466:EOANSP]2.0.CO;2] [PMID: 16637728]

13. Goel A, Singh A, Gupta T, Gambhir RS. Evaluation of surface roughness of enamel after various bonding and clean-up procedures on enamel bonded with three different bonding agents: An in-vitro study. J Clin Exp Dent. 2017; 9:608-16. [DOI: 10.4317/jced.53237] [PMID: 28512535]

14. Tiwari A, Shyagali T, Kohli S, Joshi R, Gupta A, Tiwari R. Effect of dental chair light on enamel bonding of orthodontic brackets using ligt cured based adhesive system: An in-vitro study. Acta Inform Med. 2016; 24:237-41. [DOI: 10.5455/aim.2016.24.317-321]

15. Ozturk B, Malkoc S, Koyuturk AE, Catalbas B, Ozer F. Influence of different tooth types on the bond strength of two orthodontic adhesive systems. Eur J Orthod. 2008; 30:407-12. [DOl: 10.1093/ejo/cjn006]

16. Hobson RS, McCabe JF, Hogg SD. Bond strength to surface enamel for different tooth types. Dent Mat. 2001; 17:184-9. [DOI: 10.1016/S0109-5641(00)00068-3] [PMID: 11163390]

17. Zanarini M, Gracco A, Lattuca M, Marchionni S, Gatto MR, Bonetti GA. Bracket base remnants after orthodontic debonding. Angle Orthod. 2013; 83:885-91. [DOI: 10.2319/121112-930.1]

18. Artun J, Bergland S. Clinical trials crystal growth conditioning as an alternative to acid-etch enamel pretreatment. Am J Orthod Dentofacial Orthop. 1985; 85:333-40. [DOI: 10.1016/0002-9416(84)90190-8]

19. Montasser MA, Drummondb JL. Reliability of the Adhesive Remnant Index Score System with Different Magnifications. Angle Orthod. 2009; 79:773-6. [DOI: 10.2319/080108-398.1]

20. Janiszewska-Olszowska J, Tandecka K, Szatkiewicz T, Sporniak-Tutak K, Grocholewicz K. Three-dimensional quantitative analysis of adhesive remnants and enamel loss resulting from debonding orthodontic molar tubes. Head Face Med. 2014; 10:1-6. [DOI: 10.1186/1746-160X-10-37] [PMID: 25208969]

21. Kechagia A, Zinelis S, Pandis N, Athanasiou AE, Eliades T. The effect of orthodontic adhesive and bracket-base design in adhesive remnant index on enamel. J World Fed Orthod. 2015; 4:18-22. [DOI: 10.1016/j.ejwf.2014.12.002]

22. RyfS, Flury S, Palaniappan S, Lussi A, Meerbeek B, Zimmerli B. Enamel loss and adhesive remnants following bracket removal and various clean-up procedures in vitro. Eur J Orthod. 2012; 34:25-32. [DOI: 10.1093/ejo/cjq128] [PMID: 21228118]

23. Leea M, Kanavakisb G. Comparison of shear bond strength and bonding time of a novel flash-free bonding system. Angle Orthod. 2016; 86:265-70. [DOI: 10.2319/011715-37.1] [PMID: 25970652]

24. Faria EM, Guiraldo RD, Berger SB, Correr AB, Correr-Sobrinho L, Contreras EF, et al. In vivo evaluation of the surface roughness and morphology of enamel bracket removal and polishing by different techniques. Am J Orthod Dentofacial Orthop. 2015; 147:324-9. [DOI: 10.1016/j.ajodo.2014.10.033] [PMID: 25726399] 
25. Bonetti GA, Zanarini M, Parenti SI, Lattuca M, Marchionni S, Gatto MR. Evaluation of enamel surfaces after bracket debonding: An in-vivo study with scanning electron microscopy. Am J Orthod Dentofacial Orthop. 2011; 140:696-702.

[DOI: 10.1016/j.ajodo.2011.02.027] [PMID: 22051490]
26. Santos Oliveira BL, Costa AR, Correr AB, Crepaldi MV, Correr-Sobrinho L, Bento dos Santos JC. Influence of adhesive and bonding material on the bond strenght of bracket to bovine tooth. Braz J Oral Sci. 2017; 16:1-7. [DOI: 10.20396/bjos.v16i1.8650493]

Received: 11.10.2017 • Accepted: 19.02.2018 


\title{
Procena indeksa zaostalog adheziva posle uklanjanja metalnih bravica primenom programa AutoCAD
}

\author{
Adriana Arbutina ${ }^{1}$, Marijana Arapović-Savić1, Mirjana Umićević-Davidović1, Irena Kuzmanović \\ Radman', Saša Marin ${ }^{3}$ \\ `Univerzitet u Banjoj Luci, Medicinski fakultet, Katedra za ortopediju vilica, Banja Luka, Republika Srpska, Bosna i Hercegovina; \\ ¿Univerzitet u Banjoj Luci, Medicinski fakultet, Katedra za bolesti zuba, Banja Luka, Republika Srpska, Bosna i Hercegovina; \\ ${ }^{3}$ Univerzitet u Banjoj Luci, Medicinski fakultet, Katedra za oralnu hirurgiju, Banja Luka, Republika Srpska, Bosna i Hercegovina
}

\begin{abstract}
KRATAK SADRŽAJ
Uvod Po završetku terapije fiksnim ortodontskim aparatima neophodno je ukloniti bravice i prstenove sa zuba, odgovarajućim postupkom. Cilj ovog rada je bio da se utvrdi najčešći način prekida veze između zuba i bravica prilikom uklanjanja metalnih bravica, kao i da se uporedi način prekida veze između metalnih bravica i gornjih i donjih premolara.

Materijal i metod rada Na 154 humana premolara, ekstrahovana u ortodontske svrhe, lepljene su metalne bravice Aspire kompozitnim materijalom. Posle njihovog odlepljivanja izmerena je površina preostalog adheziva na zubima i na bravicama. Primenom Indeksa zaostalog adheziva (Adehsive remnant index - ARI) izvršena je procena načina prekida veze između zuba i metalnih bravica. Rezultati Prosečna vrednost površine preostalog adheziva nakon uklanjanja bravica sa gornjih premolara je iznosila $12,06 \mathrm{~mm}^{2}$, dok je ova vrednost kod donjih premolara iznosila $9,32 \mathrm{~mm}^{2}$. Prosečna vrednost površine preostalog adheziva na bravicama koje su uklonjene sa gornjih premolara je iznosila $0,37 \mathrm{~mm}^{2}$, dok je ova vrednost kod bravica uklonjenih sa donjih premolara iznosila 2,08 $\mathrm{mm}^{2}$, te je između ovih vrednosti utvrđena statistički značajna razlika. Najčešće zastupljena ocena $\mathrm{ARI}_{\text {zuba }}$ na ukupnom nivou je bila ocena $3(85,71 \%)$, dok je najčešće zastupljena ocena $A_{\text {bravica }}$ na ukupnom nivou bila ocena $0(85,71 \%)$.

Zaključak Najčešći način prekida veze između zuba i bravice prilikom uklanjanja metalnih bravica je bio između baze bravice i površine lepka. Između vrednosti površine preostalog adheziva na gornjim i donjim premolarima kao i na bravicama utvrđena je statistički značajna razlika.
\end{abstract}

Ključne reči: uklanjanje bravica; površina adheziva; indeks zaostalog adheziva (ARI)

\section{UVOD}

Terapija fiksnim ortodontskim aparatima predstavlja jedan od najčešće korišćenih postupaka za ispravljanje ortodontskih nepravilnosti i postizanje pravilnih okluzalnih odnosa. Po završetku ortodontske terapije neophodno je ukloniti bravice i prstenove sa zuba, kao i ostatke adheziva. Način odlepljivanja bravica sa površine zuba zavisi od vrste bravica koje se koriste tokom terapije (metalne, keramičke ili plastične). Metalne bravice se uklanjaju odgovarajućim kleštima primenom vuče, torzije ili smicanja $[1,2]$.

Nekoliko faktora utiču na jačinu veze između zuba i bravica: vrsta adhezivnih sistema koji se koriste za lepljenje bravica, vrsta kiseline i dužina perioda kondicioniranja gleđi tokom pripreme zuba, veličina i vrsta bravica, dizajn baze bravice i prisustvo pljuvačke, odnosno mogućnost obezbeđivanja suvog radnog polja tokom sprovođenja postupka postavke fiksnog ortodontskog aparata. Navedeni faktori, zajedno sa vrstom i načinom primene instrumenata za uklanjanje bravica, utiču na način prekida veze između zuba i bravica, a samim tim i na količinu preostalog adheziva na zubima i na bravicama [3-6].

Smatra se da optimalna jačina veze između zuba i metalnih bravica iznosi od 5,9 MPa do $8 \mathrm{MPa}$. Ukoliko je jačina veze veća od navedenih vrednosti, pojavljuje se mogućnost oštećenja gleđi zuba prilikom samog postupka uklanjanja fiksnog ortodontskog aparata. Upravo u momentu uklanjanja bravica kleštima postoji najveći rizik od nastanka frakture gleđi. Na mestu frakture dolazi do pojačane akumulacije plaka i pojave pigmentacija. Prilikom postupka uklanjanja fiksnog ortodontskog aparata, do prekida veze između bravice i površine zuba može doći na nekoliko mesta: u bravici, između bravice i adheziva, u adhezivu, između gleđi i adheziva, u gleđi i mešoviti prelom (kombinacija navedenih). Poželjno je da nakon uklanjanja bravica lepak ostane na površini zuba, kako bi se izbegla mogućnost pojave gleđnih pukotina $[2,7,8]$.

Prilikom uklanjanja metalnih bravica, po završenoj terapiji fiksnim ortodontskim aparatima, najčešće dolazi do prekida veze između adheziva i baze metalne bravice, prilikom čega se smanjuje mogućnost pojave mikrooštećenja gleđi tokom izvođenja ovog postupka [10-14].

Pojedini autori su ukazali na međuzavisnost morfoloških karakteristika zuba i načina prekida veze između zuba i bravica, jer su uočili da veće količine lepka ostaju na bukalnim površinama zuba gornje vilice nakon uklanjanja metalnih bravica. Studije Hobsona i saradnika i Ozturka i saradnika su istakle da razlike u morfološkim karakteristikama između zuba utiču na jačinu ostvarene veze između bravice i zuba, bez obzira na vrstu korišćenog adhezivnog sistema $[15,16]$.

Zanarini i saradnici su određujući površinu preostalog lepka samo na bravicama, uočili razliku između vrednosti površine preostalog adheziva na bazama bravica uklonjenih sa zuba gornjeg i donjeg zubnog luka. Utvrdili su da veća količina adheziva ostaje na bravicama koje su uklonjene sa zuba gornjeg zubnog luka [17].

Jedna od najčešće korišćenih metoda za utvrđivanje načina i mesta prekida veze između površine zuba i baze bravice jeste upotreba indeksa zaostalog adheziva (Adhesive Remnant Index - ARI), kojeg su u istraživanje uveli Artun i Bergland 1984. godine [18]. Primenom ovog indeksa omogućeno je određivanje mesta prekida veze prilikom korišćenja različitih vrsta bravica i adhezivnih sistema, na jednostavan način. Procena preostalog adheziva na zubima i bravicama sprovodi se primenom ARI indeksa zuba $\left(\mathrm{ARI}_{\text {zuba }}\right)$ i ARI indeksa bravica $\left(\mathrm{ARI}_{\text {bravica }}\right)$. Za određivanje površine zaostalog adheziva na zubima i bravicama često se koristi stereomikroskopija, ali i određeni kompjuterski programi $[17,19,20]$. 
Cilj ovog istraživanja je bio da se utvrdi najčešći način prekida veze između zuba i metalnih bravica primenom ARI indeksa i programa AutoCAD, te da se ispita postojanje razlike u prekidu veze između gornjih i donjih premolara i metalnih bravica.

\section{MATERIJAL I METOD RADA}

U toku ovog istraživanja su prikupljena 154 humana premolara ekstrahovana u ortodontske svrhe (77 gornjih premolara i 77 donjih premolara). Kriterijum za izbor zuba je podrazumevao da zubi imaju intaktnu oralnu i bukalnu površinu, bez vidljivih oštećenja, belih mrlja i karioznih lezija i da nisu prethodno bili izlagani hemijskim agensima poput vodonik-peroksida ili nekoj od kiselina u svrhu nagrizanja. Stereomikroskopijom (uvećanje $10 \times$ ) procenjeno je da li prikupljeni uzorak ispunjava kriterijum. Zubi su se čuvali do početka istraživanja u fiziološkom rastvoru sa $0,1 \%$ timolom, kako bi se sprečila pojava dehidracije gleđi zuba. Pre samog eksperimenta zubi su mehanički očišćeni četkicom i neabrazivnom pastom bez fluora. Srednja trećina bukalne površine svakog zuba je tretirana 38\% ortofosfornom kiselinom u trajanju od 20 sekundi, a potom isprana mlazom voda-vazduh 30 sekundi i posušena još 30 sekundi. Na bukalnu površinu 154 zuba je nanošen Aspire orthodontic adhesive 7GM (OC Orthodontics, USA) prema uputstvu proizvođača, a potom je izvršena njegova polimerizacija u trajanju od 10 sekundi. Nakon toga, metalne bravice za premolare (Ortho Organizers Elite OptiMIM, Henry Schein Orthodontics, USA) postavljane su instrumentom za pozicioniranje (Ixion positioner, DB Orthodontics, Zapadni Jorkšir, UK) na pripremljenu površinu zuba i lepljene su pomoću Aspire orthodontic adhesive 5GM (OC Orthodontics, USA) (slika 1 i 2). Polimerizacija je izvršena LED lampom u trajanju od 40 sekundi, po uputstvu proizvođača.

Zubi su ostavljeni u veštačkoj pljuvački na sobnoj temperaturi, tokom 48 sati, kako bi adhezivni sistem dostigao svoju maksimalnu snagu. Kao izvor veštačke pljuvačke korišćen je Biotene gel (GlaxoSmithKline, Belgija). Nakon 48 sati bravice su odlepljene kleštima za skidanje bravica (Ixion bracket removing plier, DB Orthodontics, West Yorkshire, UK). Nakon sprovođenja postupka pripreme uzorka koji se sastojao u fiksiranju zuba i bravica, omogućeno je fotografisanje bukalnih površina zuba i baza bravica digitalnim fotoaparatom Nikon D5100. Fotografisanje je sprovedeno uz upotrebu makroskopskog objektiva, pri adekvatnom svetlu sa udaljenosti od $20 \mathrm{~cm}$. Fiksiran uzorak je bio postavljen na foliju sa milimetarskom podelom koja je služila kao referentna mera u okviru fotografisanog kadra i osnova za kalibraciju fotografije u programu AutoCAD (Autodesk inc. San Rafael, CA, USA) [21]. Za određivanje površine preostalog adheziva na zubu i bazi bravice, kao i za određivanje površine baze bravice, korišćen je program AutoCAD, najčešće korišćen program firme Autodesk za izradu inženjerske projektne dokumentacije u 2D i 3D projektovanju. Nakon kalibracije fotografije u AutoCAD-u, polilinijama u vidu „'zatvorenih poligona“ preko fotografija označene su površine preostalog adheziva na zubu i bazi bravice, kao i površina bravice, te su automatski dobijene vrednosti označenih parametara (Slika 3). Procena preostalog adheziva na zubima i bravicama urađena je primenom ARI indeksa zuba i ARI indeksa bravica. ARI ${ }_{\text {zuba }}$ se koristio za procenu površine preostalog adheziva na gleđi i određen je po sledećoj formuli: površina zuba sa preostalim adhezivom/površina baze bravice $\times 100$. ARI ${ }_{\text {bravica }}$ se koristio za procenu površine preostalog adheziva na bravicama, a dobijen je po formuli: površina bravice sa preostalim adhezivom/površina baze bravice $\times 100$.

Vrednost površine preostalog adheziva na zubima se ocenjivala pomoću $\mathrm{ARI}_{\text {zuba }}$, tako da je za određene vrednosti preostalog adheziva dodeljena ocena od 0 do 3 na sledeći način:

ocena $0-0 \%$ adheziva na površini zuba,

ocena 1 - manje od $50 \%$ adheziva preostalog na površini zuba,

ocena 2 - više od $50 \%$ adheziva preostalog na površini zuba i ocena $3-100 \%$ adheziva na površini zuba.

Površina preostalog adheziva na bravicama je bila ocenjena primenom $\mathrm{ARI}_{\text {bravica }}$, na sledeći način:

ocena 0 - manje od $10 \%$ adheziva preostalog na površini bravice,

ocena 1 - više od $10 \%$ ali manje od $50 \%$ adheziva preostalog na površini bravice,

ocena 2 - više od $50 \%$ ali manje od od $90 \%$ adheziva preostalog na površini bravice $\mathrm{i}$

ocena 3 - više od $90 \%$ adheziva na površini bravice [18].

\section{Statistička obrada podataka}

Kvalitativni podaci (ocene ARI indeksa) prikazani su kroz broj pojava i procentualnu zastupljenost. Za prikaz površine preostalog adheziva na zubu i na bravici nakon uklanjanja bravica korišćeni su pokazatelji deskriptivne statistike (aritmetička sredina, standardna devijacija, ekstremne vrednosti). Za upoređivanje srednjih vrednosti obeležja korišćen je parametarski Student $t$ test za nezavisne uzorke. Kao statistički značajne uzimane su vrednosti u kojima je p < 0,05, s tim da su vrednosti u kojima je $\mathrm{p}<0,01$ isticane kao statistički veoma značajne. Za utvrđivanje stepena povezanosti posmatranih obeležja korišćena je Pirsonova parametarska korelacija.

\section{REZULTATI}

Prosečna vrednost površine bravica Ortho Organizers Elite OptiMIM za premolare, koje su lepljene na površinu 154 premolara, iznosila je $11,07 \mathrm{~mm}^{2}$. Nakon uklanjanja bravica, programom AutoCAD su određene vrednosti površine preostalog adheziva na zubima i na bravicama. Prosečna vrednost preostalog adheziva nakon uklanjanja bravica sa gornjih premolara je iznosila $12,06 \mathrm{~mm}^{2}$, dok je ova vrednost kod donjih premolara iznosila $9,32 \mathrm{~mm}^{2}$. Primenom parametarskog Student $\mathrm{t}$ testa, za upoređivanje srednjih vrednosti obeležja utvrđeno je da je bilo statistički značajne razlike u vrednostima preostalog adheziva na gornjim i donjim premolarima nakon uklanjanja bravica. Ovi rezultati su prikazani u Tabeli 1 .

Prosečna vrednost površine preostalog adheziva na bravicama koje su uklonjene sa gornjih premolara je iznosila 0,37 $\mathrm{mm}^{2}$, dok je ova vrednost kod donjih premolara iznosila 2,08 $\mathrm{mm}^{2}$. Primenom parametarskog Student $\mathrm{t}$ testa, za upoređivanje srednjih vrednosti obeležja je utvrđeno da je bilo statistički veoma značajne razlike u vrednostima preostalog adheziva na bravicama uklonjenim sa gornjih i donjih premolara. Ovi rezultati su prikazani u Tabeli 2.

U tabelama 3 i 4 prikazana je distribucija $\mathrm{ARI}_{\text {zuba }}$ i ARI $_{\text {bravica }}$ za gornje i donje premolare i na ukupnom nivou. Najčešće za- 
stupljena ocena $\mathrm{ARI}_{\text {zuba }}$ na ukupnom nivou je bila ocena 3. Čak kod 132 zuba $(85,71 \%)$ utvrđena je ocena 3 nakon uklanjanja bravica, 13 zuba $(8,44 \%)$ je dobilo ocenu 0 , ocenu 2 je imalo sedam zuba (1,3\%), dok su ocenu 1 imala svega dva zuba (1,3\%). Najčešće zastupljena ocena $\mathrm{ARI}_{\text {bravica }}$ na ukupnom nivou je bila ocena $0(132,85,71 \%), 13$ bravica $(8,44 \%)$ je dobilo ocenu 3, ocenu 1 je imalo sedam bravica $(4,54 \%)$, dok su ocenu 2 imale svega dve bravice $(1,3 \%)$.

Povezanost između prosečnih vrednosti $\mathrm{ARI}_{\text {zuba }}$ za gornje i donje premolare izrežena je pomoću koeficijenta Pirsonove linearne korelacije. Utvrđena je statistički značajna, pozitivna i veoma jaka povezanost između prosečnih vrednosti $\mathrm{ARI}_{\text {zuba }} \mathrm{za}$ gornje i donje premolare $(\mathrm{r}=0,53, \mathrm{p}<0,01)$. Takođe, utvrđena je statistički značajna, pozitivna i veoma jaka korelacija između prosečnih vrednosti $\mathrm{ARI}_{\text {bravica }}$ za bravice lepljene na gornje $\mathrm{i}$ donje premolare $(r=0,53, \mathrm{p}<0,01)$ (Tabela 5).

\section{DISKUSIJA}

U ovom istraživanju korišćene su metalne bravice, s obzirom na to da fiksni ortodontski aparati sa metalnim bravicama često predstavljaju metod izbora za postizanje uspešnog terapijskog rezultata. Nakon uklanjanja bravica sa zuba utvrđena je statistički značajna razlika u vrednostima površine preostalog adheziva na gornjim i donjim premolarima,

kao i na bravicama koje su uklonjene sa navedenih zuba, ali i razlika u vrednostima ARI indeksa. Postojanjem jasnih razlika između morfoloških karakteristika krune gornjih i donjih premolara, a samim tim i konveksiteta bukalne površine različitog stepena izraženosti, mogla bi se objasniti utvrđena statistički značajna razlika u vrednostima površine preostalog adheziva na njima. Pojedini autori su ukazali na postojanje razlike $u$ vrednostima površine preostalog adheziva na gornjim i donjim zubima koristeći bravice u svrhu ispitivanja. Tako su Zanarini i saradnici svoje istraživanje sproveli na 100 metalnih bravica, koje su uklonjene po završetku terapije fiksnim ortodontskim aparatima kod 60 pacijenata. Primenom programa Image J na fotomikrografijama dobijenim skenirajućom elektronskom mikroskopijom, merili su površinu preostalog adheziva na bazama bravica. Uočili su statistički značajnu razliku između vrednosti površina preostalog adheziva na bazama bravica, između zuba gornjeg i donjeg zubnog luka, što je u skladu i sa rezultatima ovog istraživanja [17].

Najčešće zastupljena ocena $\mathrm{ARI}_{\text {zuba }}$ u ovom istraživanju bila je ocena 3, koja je utvrđena kod čak 132 zuba. Kod 13 zuba je dodeljena ocena 0 , sedam zuba je dobilo ocenu 2 , a samo dva zuba su imala ARI ocenu 1. Ovaj rezultat ukazuje na to da je najčešće mesto prekida veze zub-bravica bilo upravo između adheziva i baze metalnih bravica, čime je onemogućeno nastajanje mikropukotina prilikom uklanjanja adheziva. In vitro studijama Ryfa i saradnika, kao i Singa i Kumaria, koji su primenom ARI zuba ispitivali prekid veze između zuba i bravice prilikom uklanjanja metalnih bravica kleštima sa humanih premolara, takođe je uočena veća količina preostalog lepka na zubu. Najviše zastupljena ARI ocena je bila ocena 3, koja je ukazala na to da je mesto prekida veze najčešće nastajalo između baze bravice i lepka [22,23].

ARI indeks takođe se koristi i u in vivo studijama, prilikom čijeg izvođenja je neophodno uzeti precizne otiske zuba sa kojih su uklonjene bravice. Ovakve studije još mogu da ukažu na zna- čaj pojedinih faktora na mesto nastanka prekida veze između zuba i bravice, koje u in vitro studijama nije moguće u potpunosti ostvariti, kao što su: duži period izlaganja bravica i lepka dejstvu pljuvačke te promenama $\mathrm{pH}$ vrednosti koje se dešavaju u usnoj duplji prilikom unosa određene vrste pića i hrane, kao i izloženost postavljenih bravica silama tokom mastikacije. Na osnovu otisaka zuba mogu se napraviti studijski modeli čija se površina može posmatrati stereomikroskopijom, što dalje pruža mogućnost pravljenja i fotomikrografija. Otisci takođe mogu da budu korišćeni kao uzorci sa SEM analizu, čime se još preciznije može utvrditi vrednost površine preostalog adheziva na zubu. Rezultati većine in vivo studija, koje su ispitivale mesto prekida veze između metalnih bravica i zuba, nisu pokazale veća odstupanja u dobijenim vrednostima ARI indeksa u odnosu na in vitro studije [24].

Bonetti i saradnici su svoje istraživanje sproveli na 12 studenata dentalne medicine, kojima su na druge premolare lepili metalne bravice i to na 12 premolara Victory Series; na tri $\mathrm{Mu}$ nitek, Monrovia; California, pomoću kompozitnog materijala Transbond XT, a na preostalih 12 premolara APC II Victory Series; $3 M$ Unitek, sa već fabrički nanesenim adhezivom. Nakon uklanjanja bravica ispitivali su površinu preostalog adheziva na zubima i bravicama primenom ARI indeksa. Utvrdili su da nije bilo statistički značajne razlike u distribuciji ARI ocena između dve grupe premolara, a najčešća ocena je bila ocena 3 , što je u skladu i sa rezultatima ovog istraživanja [25].

Jedan od faktora koji utiče na način prekida veze između zuba i bravice prilikom uklanjanja bravica predstavlja i vrsta bravice koja se koristi tokom terapije. Tako Mirzakouchaki i saradnici u svojoj studiji koju su sproveli na 120 intaktnih humanih premolara, na koje su postavljali metalne i keramičke bravice, zaključuju da je kod zuba na koje su bile postavljene metalne bravice veći deo adheziva ostao na zubu, za razliku od zuba na koje su bile postavljene keramičke bravice [7].

Osim materijala koji se koristi za izradu bravice, način retencije (hemijska ili mehanička) i dizajn baze bravice utiču kako na jačinu ostvarene veze sa zubom, tako i na način njenog prekida prilikom uklanjanja bravica. Henkin i saradnici su u svom istraživanju koje je sprovedeno na 105 goveđih zuba, ispitivali način prekida veze između zuba i sedam različitih tipova metalnih bravica (Morelli ${ }^{T M}$, American Orthodontics ${ }^{T M}$, TP Orthodontics ${ }^{T M}$, Orthometric $^{T M}$, Tecnident ${ }^{T M}$, Unident ${ }^{T M}$, Abzil-3M $\left.{ }^{T M}\right)$. Nakon njihovog odlepliivanja određivali su ARI indeks stereomikroskopijom. Uočili su različitu distribuciju ARI ocena kod zuba sa različitim tipom bravica. Najčešća ocena kod zuba na koje su lepljene bravice Unident ${ }^{T M}$ bila je ocena 3, što je u skladu sa rezultatima ovog istraživanja. Na zubima na kojima su lepljeni drugi tipovi metalnih bravica najčešća ocena je bila ocena 1 , što se može objasniti različitim oblikom i strukturom baze metalnih bravica. Bravice Unident $^{T M}$ imaju sličan oblik i mrežastu strukturu baze kao bravice OrthoOrganizer koje su korišćene u ovom istraživanju, što je moglo uticati na sličan rezultat za ARI indeks [10].

Prilikom sprovođenja ovog istraživanja korišćen je svetlosno-polimerizujući kompozitni materijal Aspire (Ortho Classic Orthodontics, USA), kojeg karakteriše produženo radno vreme. Korišćeni materijal ne poseduje transparentnost, što omogućava njegovo lakše uočavanje na površini zuba. Veliki broj istraživanja u kojima je određivan ARI indeks ističe značaj vrste adhezivnog sistema koji se koristi za postavku fiksnog ortodontskog aparata [26]. 
Prilikom postavke fiksnog ortodontskog aparata primećeno je da ponekad može doći do prevremene polimerizacije kompozitnog materijala koji se koristi za lepljenje bravica pod uticajem reflektora na stomatološkoj stolici. Ovo se odnosi na situacije kada dođe do vezivanja materijala pre nego što se bravica postavi u pravilan položaj na površinu zuba. Pojedini autori, kao što su Tiwari i saradnici, ispitivali su i uticaj svetla, odnosno jačine reflektora stomatološke stolice na jačinu veze, kao i na mesto nastanka prekida veze između zuba i bravica lepljenih Transbond XT (3M Unitec, Monrovia, Callif, USA) svetlosno-polimerizujućim kompozitnim materijalom. Svoju studiju su sproveli na 60 humanih premolara, ekstrahovanih $\mathrm{u}$ ortodontske svrhe. Najčešća ocena ARI indeksa nakon odlepljivanja metalnih bravica je bila 3, što je ukazalo da je najčešće mesto prekida veze između zuba i bravica bilo na granici lepka i baze bravice, a to je u skladu sa rezultatima ovog istraživanja. Autori su uočili da svetlo reflektora stomatološke stolice ipak nije imalo značajnijeg uticaja na jačinu i način prekida veze između zuba i bravice [14].
U ovom istraživanju je pronađena razlika u vrednostima površine preostalog adheziva između gornjih i donjih premolara nakon odlepljivanja bravica. Razlika je pronađena i u vrednostima površine preostalog lepka na bravicama koje su odlepljene sa ispitivanih premolara. S obzirom na to da je studija obavljena isključivo na premolarima, $u$ daljim istraživanjima mogla bi se ispitati razlika u površini preostalog adheziva i na sekutićima $\mathrm{i}$ molarima gornjeg i donjeg zubnog luka nakon uklanjanja bravica, zbog postojanja morfoloških razlika u obliku ovih zuba.

\section{ZAKLJUČAK}

Prilikom uklanjanja metalnih bravica najčešći način prekida veze je bio između adheziva i baze bravice. Prilikom uklanjanja bravica utvrđena je statistički značajna razlika između vrednosti površine preostalog adheziva na gornjim i donjim premolarima, kao i između vrednosti preostalog adheziva na bazama bravica uklonjenih sa gornjih i donjih premolara. 